\title{
MOLECULAR INSIGHTS INTO THE BIOGEOGRAPHY AND SPECIES STATUS OF NEW ZEALAND'S ENDEMIC LATRODECTUS SPIDER SPECIES; L. KATIPO AND L. ATRITUS (ARANEAE, THERIDIIDAE)
}

\author{
James W. Griffiths ${ }^{1}$, Adrian M. Paterson and Cor J. Vink ${ }^{2,3}$ : Ecology \& \\ Entomology Group, PO Box 84, Lincoln University, New Zealand. E-mail: \\ cor.vink@arachnology.org
}

\begin{abstract}
New Zealand's endemic sand dune Latrodectus widow spider species, L. katipo and L. atritus, possess behavioral and physiological attributes likely to promote dispersal over large distances. Morphological, physiological and behavioral similarities between L. katipo and L. hasselti, an Australian endemic, suggest gene flow may occur across the Tasman Sea. In this study we examine intraspecific and interspecific genetic relationships within the ND1 gene region between L. katipo, L. atritus, L. hasselti and $L$. hesperus to assess whether the genetic evidence supports current taxonomic species designations. We found low interspecific pairwise distances among L. katipo and L. atritus populations, suggesting either introgression, incomplete lineage sorting, or that the current taxonomic distinction between the two species may be invalid. Parsimony and maximum likelihood analyses were inconclusive as to the relationships between the New Zealand Latrodectus species and the Australian L. hasselti. Low pairwise distances between $L$. hasselti and the New Zealand widow fauna indicated that L. katipo and L. atritus were not present in New Zealand before the fragmentation of Gondwana.
\end{abstract}

Keywords: Latrodectus, New Zealand, Australia, dispersal, molecular phylogenetics

New Zealand's endemic Latrodectus Walckenaer 1805 fauna is considered to comprise two endemic species, L. katipo Powell 1870 and L. atritus Urquhart 1890 (Forster \& Forster 1999). Latrodectus atritus was originally described as a subspecies of L. katipo (Urquhart 1890) and was proposed as a subspecies of L. hasselti Thorell 1870 by Parrott (1948), and a junior synonym of L. mactans (Fabricius 1775) by Levi (1959). McCutcheon (1976) and Forster \& Kingsford (1983) argued that $L$. atritus is a separate species to L. katipo and Forster (1995) elevated L. atritus to species but did not provide any taxonomic justification. The only reported morphological difference between L. atritus and L. katipo is coloration, which is usually unreliable for separating spider species but can be useful in sep-

\footnotetext{
${ }^{1}$ Current address: Department of Conservation, East Coast/Hawke's Bay Conservancy, PO Box 668, Gisborne, New Zealand.

${ }^{2}$ Current address: Department of Biology, San Diego State University, San Diego, CA 92182-4614, USA.

${ }^{3}$ Corresponding author.
}

arating Latrodectus species (McCrone \& Levi 1964). Latrodectus atritus females do not have the red median stripe on the dorsal surface of the abdomen that L. katipo has (McCutcheon 1976; Forster \& Kingsford 1983; Forster \& Forster 1999) and the males of the two species have slight differences in color (Forster \& Kingsford 1983). Forster \& Kingsford (1983) also reported differences between the species in the time it took for spiderlings to emerge from the eggsac. Forster \& Forster (1999) noted that L. atritus eggs and spiderlings need higher temperatures than L. katipo and they also stated that "laboratory studies show that they do not generally crossmate but when they do, the eggs are infertile" but no data was included in the publication to support this. Both New Zealand species inhabit coastal dune systems and commonly build webs in low growing plants and driftwood or flotsam. Although the niches occupied by L. katipo and L. atritus are similar, their known distributions are distinct. Latrodectus katipo inhabits coastal dunes in the northern half of South Island and the southern half of North Island, whereas 
L. atritus inhabits coastal dunes in the northern half of North Island. There is an overlap in the species' distributions in Taranaki on the west coast of North Island (Forster \& Forster 1999) and in Hawkes' Bay on the east coast North Island.

Discriminating between Latrodectus species using morphology has always been problematic (Levi 1983) and the distinction between L. katipo and the Australian L. hasselti is minimal. There is no difference between the male pedipalp and female external and internal genitalia of the two species (Parrott 1948; Levi 1959) but that is often the case in Latrodectus (Levi 1983). Forster \& Forster (1999) state that the most definitive morphological character that separates the two species is the dense covering of short, fine hairs on the body of $L$. katipo compared to the long fine hairs and stouter short hairs on L. hasselti. Latrodectus hasselti females are usually larger, their webs are stronger and usually yellowish in color (Forster \& Forster 1999) and this species performs a stereotyped behavior of sexual cannibalism (Forster 1992). Laboratory studies examining interspecific interactions have shown that L. hasselti females will not mate with L. katipo males (Forster 1992, 1995). However, in their phylogenetic study of Latrodectus, Garb et al. (2004) found that L. katipo and $L$. hasselti were closely related (4.9\% uncorrected divergence in a $428 \mathrm{bp} \mathrm{sec}-$ tion of the mitochondrial gene cytochrome oxidase subunit I (COI)).

Recent research demonstrates that L. katipo and L. atritus are probably good dispersers. Spiderlings of both species are able to disperse by ballooning and adult females may be able to disperse on driftwood at sea under optimal conditions (Griffiths 2002). It is uncertain how far L. katipo, L. atritus, or L. hasselti could disperse by these means, but other ballooning spider species have been recorded landing on ships up to $300 \mathrm{~km}$ from land (Gertsch 1979), indicating that ballooning spiders may travel substantial distances. Furthermore, spiders recorded from driftwood and flotsam at sea, suggest that water-borne spiders could also disperse over large distances (Foelix 1996) and adult L. hasselti can survive more than 300 days without food (Forster \& Kavale 1989). This evidence may explain why L. katipo and L. atritus distributions span numerous geographic barriers such as headlands, estuaries, rivers and areas of open sea $(<30$ $\mathrm{km})$ and may account for morphological, physiological and molecular similarities between the New Zealand Latrodectus fauna and L. hasselti, which is considered endemic to Australia (Parrott 1948; Levi 1959; Forster \& Kingsford 1983; Garb et al. 2004). As yet, however, the influence dispersal may have had on the biogeography of L. katipo and L. atritus has not been investigated. Moreover, behavioral, morphological, physiological and molecular similarities between L. katipo and the Australian endemic, L. hasselti, have not been adequately explained.

In this paper, we examine intraspecific and interspecific genetic relationships within the NADH dehydrogenase subunit 1 (ND1) mitochondrial gene region between $L$. katipo, $L$. atritus, L. hasselti and $L$. hesperus Chamberlin \& Ivie 1935 (all part of the strongly supported "mactans clade" in Garb et al. 2004) to assess the degree of separation between the New Zealand and Australian Latrodectus species and whether genetic evidence supports current taxonomic species designations. The ND1 gene region was chosen because it is fast evolving and has been successfully used to examine genetic differences between spider species and populations (Hedin 1997a, 1997b; Masta 2000; Johannesen et al. 2002; Maddison \& Hedin 2003; Masta \& Maddison 2002; Vink \& Paterson 2003).

\section{METHODS}

Adult female L. katipo and L. atritus were collected from eight sites around New Zealand (Fig. 1) and were stored in 95-100\% EtOH at $-80{ }^{\circ} \mathrm{C}$ to maintain high quality DNA. Voucher specimens are stored at the Ecology and Entomology Group, Research Collection, Lincoln University, New Zealand. Specimens were collected from sites that were selected throughout the distributions of both species. One specimen per population of $L$. katipo was collected from Kaitorete Spit $\left(43^{\circ} 50^{\prime} \mathrm{S}, 172^{\circ} 31^{\prime} \mathrm{E}\right)$ and Waikuku Beach $\left(43^{\circ} 17^{\prime} \mathrm{S}, 172^{\circ} 43^{\prime} \mathrm{E}\right)$, Canterbury, from Farewell Spit $\left(40^{\circ} 30^{\prime} \mathrm{S}, 172^{\circ} 48^{\prime} \mathrm{E}\right)$, Golden Bay and from Flat Point $\left(41^{\circ} 28^{\prime} \mathrm{S}, 175^{\circ} 37^{\prime} \mathrm{E}\right)$ and Herbertville $\left(40^{\circ} 29^{\prime} \mathrm{S}, 176^{\circ} 37^{\prime} \mathrm{E}\right)$ on the east coast of the lower North Island (Fig. 1). One specimen per population of L. atritus was collected from Houpoto $\left(37^{\circ} 58^{\prime} \mathrm{S}, 177^{\circ} 33^{\prime} \mathrm{E}\right)$, Rarawa $\left(34^{\circ} 44^{\prime} \mathrm{S}, 173^{\circ} 05^{\prime} \mathrm{E}\right)$ and Opoutere 
$\left(37^{\circ} 24^{\prime} \mathrm{S}, 175^{\circ} 56^{\prime} \mathrm{E}\right)$ in the upper North Island (Fig. 1). Latrodectus hasselti were collected from Myalup, Western Australia $\left(33^{\circ} 06^{\prime} \mathrm{S}\right.$, $\left.115^{\circ} 41^{\prime} \mathrm{E}\right)$ and Brisbane, Queensland $\left(27^{\circ} 27^{\prime} \mathrm{S}, 153^{\circ} 02\right)$. A specimen of L. hesperus, intercepted by the New Zealand Ministry of Agriculture and Forestry on table grapes from California, USA was used as an outgroup. Although L. hesperus is common throughout western North America (Chamberlin \& Ivie 1935; Levi 1983), the identification of the $L$. hesperus specimen is tentative as a second, undescribed Latrodectus species is reported to be present in California (see Levi 1983) and the taxonomic differences between the two species are unknown. The entire front leg and hind leg from one side of each specimen were removed and washed in sterile deionized, distilled water to remove excess alcohol. Genomic DNA was extracted from samples using a proteinase-K digestion and high salt precipitation method (White et al. 1990). The DNA was suspended in 1:20 TE $(10 \mathrm{mM}$ Tris, $1 \mathrm{mM}$ EDTA, pH 8.0).

The first half $(\sim 420 \mathrm{bp})$ of the mitochondrial ND1 gene region was amplified from diluted genomics in $25 \mu \mathrm{l}$ PCR reactions using the primers N1-J-12261 and TL1-N-12718 (Hedin 1997a). Each $25 \mu$ l reaction contained $1 \times$ Taq buffer, $1 \mathrm{mM}$ dNTPs, $2 \mu \mathrm{M} \mathrm{MgCl}_{2}$, $0.4 \mu \mathrm{M}$ of each primer, 1.25 units Taq DNA polymerase (Roche), and $1 \mu$ l diluted genomic DNA. Amplification took place in a GeneAmp ${ }^{\circledR} 2400$ Thermocycler and included an initial denaturation of $4 \mathrm{~min}$. at $94{ }^{\circ} \mathrm{C}$ followed by 40 cycles of $40 \mathrm{~s}$ at $94{ }^{\circ} \mathrm{C}, 40 \mathrm{~s}$ at $45{ }^{\circ} \mathrm{C}, 40 \mathrm{~s}$ at $72{ }^{\circ} \mathrm{C}$ and a final extension of 5 min. at $72{ }^{\circ} \mathrm{C}$. The resulting PCR product was purified by precipitation with $50 \mu \mathrm{l}$ of

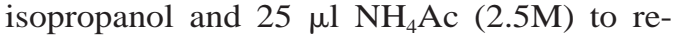
move excess salts and primers. Purified dsDNA samples were washed in $70 \% \mathrm{EtOH}$ and suspended in $6 \mu \mathrm{l}$ of sterile deionized, distilled water. All dsDNA samples were subsequently sent to the Waikato DNA Sequencing Facility where they were sequenced in both directions.

DNA sequences were aligned against a complementary-strand sequence in DNAMAN (version 4.02), and checked against hard copy chromatograms by eye. Corrections were made where necessary. The possibility of pseudogenes and polymerase errors were eliminated by the translation of the sequences to amino acids and no stop codons or frameshifts were found. A multiple alignment of all sequences was compiled in CLUSTALX (Thompson et al. 1997) and imported into PAUP* 4.0b10 (Swofford 2002) for analysis.

Data were analyzed as unordered characters using parsimony with the exhaustive option selected. Bootstrap values (Felsenstein 1985) for monophyletic groups were calculated using the branch and bound search option in PAUP*. Model test version 3.06 (Posada \& Crandall 1998) was used to select the maximum likelihood parameters and the HKY + $\Gamma$ model (Hasegawa et al. 1985) was used to estimate the maximum likelihood tree. The branch and bound option was selected in PAUP* for the maximum likelihood analysis and branches were collapsed creating polytomies if the branch length was $\leq 1 \mathrm{e}-08$. Bootstrap values for the maximum likelihood tree were calculated using a heuristic search (10000 replicates). Base frequency calculations, transition/transversion ratios, number of variable sites and the conversion of nucleotides to amino acids were conducted using MEGA version 2.1 (Kumar et al 2001).

In addition to the molecular work, 22 specimens of L. katipo and $L$. atritus from collections at the Museum of New Zealand, Otago Museum, Auckland Museum and Lincoln University Entomology Research Museum were examined for differences in male and female genitalia.

\section{RESULTS}

The nucleotide composition was $\mathrm{G}$ (guanine) depauperate $(29 \% \mathrm{~A}, 22 \% \mathrm{C}, 10 \% \mathrm{G}$, $39 \% \mathrm{~T}$ ), which is similar to that of the spider family Nesticidae (Hedin 1997a), a sister family of Theridiidae (Griswold et al. 1998). Sequence data were deposited in GenBank (Benson et al. 2002), accession numbers AY383604-AY383614.

The largest interspecific pairwise distance between $L$. katipo, L. atritus and $L$. hasselti was $1.95 \%$, whereas the smallest pairwise distance between the Australasian specimens and $L$. hesperus was $21.41 \%$ (Table 2). In contrast, the largest intraspecific pairwise distance between L. katipo specimens was 0.97 $\%$, which was the same as the largest pairwise distance between L. katipo and L. atritus 0.97 $\%$ and greater than the largest pairwise dis- 


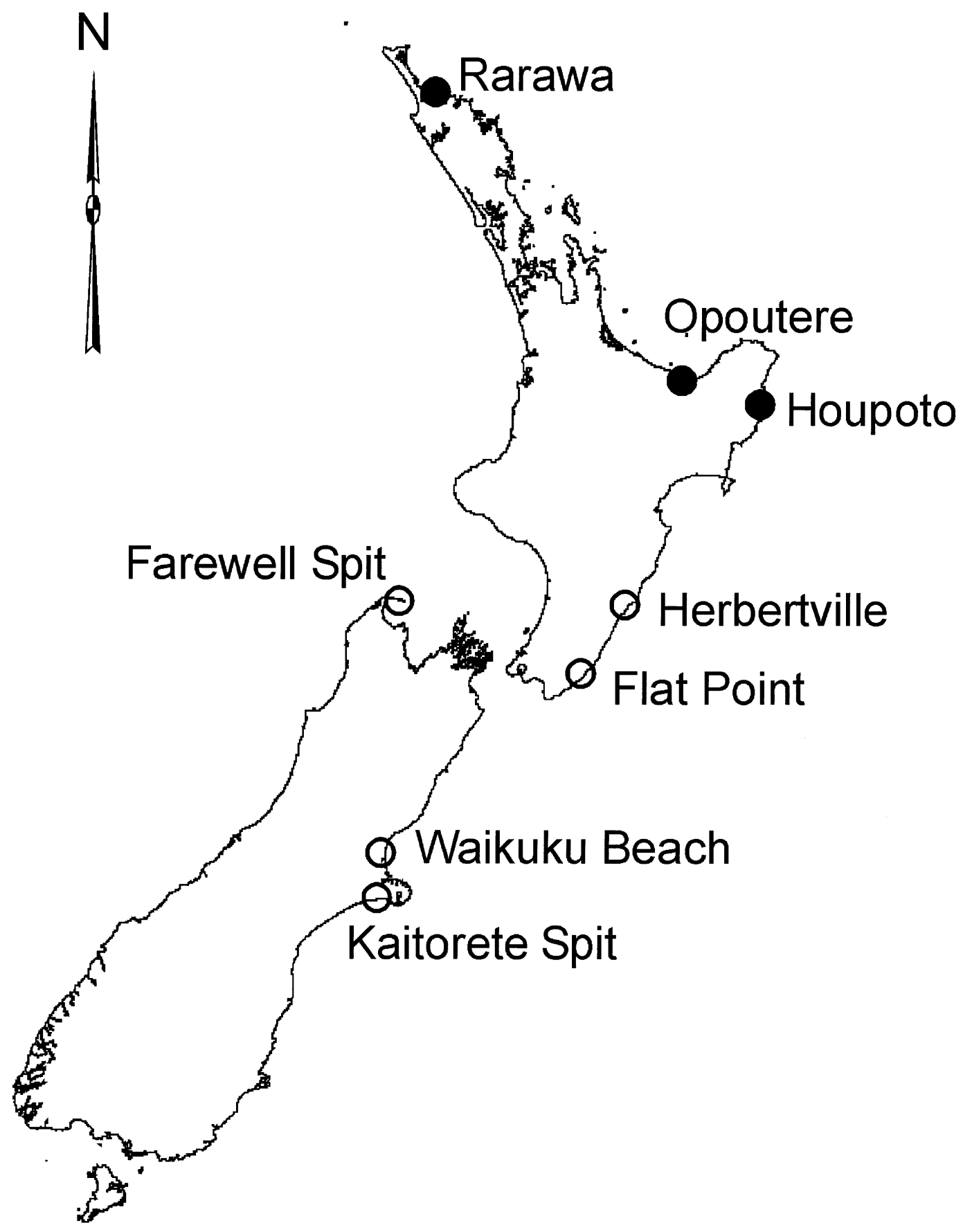

Figure 1.- Sites where L. katipo $(\bigcirc$ - unfilled circle) and L. atritus $(\bigcirc-$ filled circle) samples were collected for molecular analysis.

tance between L. atritus specimens $0.73 \%$, or L. hasselti specimens $0.00 \%$ (Table 2).

Three haplotypes of L. katipo occurred among the specimens sampled. The L. katipo specimens from Herbertville and Flat Point had identical ND1 sequences as did the specimens from Farewell Spit and Wiakuku. There were three haplotypes of $L$. atritus and all 
Table 1.-Base frequencies, transition/transversion ratios and number of variable sites at each codon position.

\begin{tabular}{lccc}
\hline & Position 1 & Position 2 & Position 3 \\
\hline Base frequencies $\%$ & T 32.8, C 18.4, & T 44.9, C 21.3, & T 40.1, C 26.4, \\
& A 36.0, G 12.7 & A 21.9, G 11.9 & A 28.7, G 4.7 \\
Transition/transversion ratio \% & 3.5 & 1.3 & 1.6 \\
Variable sites including L. hesperus & 16 & 7 & 68 \\
Variable sites excluding $L$. hesperus & 1 & 0 & 10
\end{tabular}

three specimens had different sequences. The ND1 sequences of both $L$. hasselti specimens were identical. Ninety-one nucleotides varied among the four Latrodectus species but only 11 sites varied between the L. katipo, L. atritus and L. hasselti specimens. Table 1 lists the base frequencies by base position, transition/ transversion ratios and number of variable sites at each position.

Fourteen of the 137 amino acids coded for by the ND1 sequence were variable. Only two were variable within $L$. katipo, $L$. atritus and L. hasselti. There were three Australasian haplotypes. The two $L$. hasselti specimens formed one haplotype. Latrodectus katipo from Flat Point, Herbertville and Kiatorete Spit had identical amino acids. The third amino acid haplotype consisted of L. katipo from Farewell Spit and Waikuku and L. atritus from Houpoto, Rarawa and Opoutere.

Parsimony analysis yielded 12 equally parsimonious trees, 97 steps long with a consistency index, excluding uninformative characters, of 0.714 and a retention index of 0.714 . Of the 411 characters included, 91 were variable of which four were parsimony informative. There was no consensus among the 12 trees. Maximum likelihood analysis yielded 1 tree with a score of $-\ln 883.451$. The likelihood tree (Fig. 2) had an identical topology to one of the 12 most parsimonious trees. There was no bootstrap support for any of the clades in the parsimony analysis and only very weak bootstrap support in the maximum likelihood trees (not shown on Fig. 2); 59\% for a clade containing Queensland and Western Australia, Farewell Spit and Waikuku, Houpoto, Opoutere, Rarawa, and Kiatorete Spit and 52\% for the clade containing Farewell Spit and Waikuku, Houpoto, Opoutere, and Rarawa.

There were no differences in the structure of the sclerites of the male pedipalpal bulb or the sclerites of the female external epigyne of the 22 museum specimens of $L$. katipo and $L$. atritus examined.

\section{DISCUSSION}

Although too few genetic samples were collected to gain a definitive view on intra-specific gene flow between $L$. katipo and $L$. atritus populations, an indication can be inferred from the results. The maximum interspecific pairwise distance among L. katipo and L. atritus populations was $0.97 \%$, which was smaller than most pairwise distances found in the ND1 gene region between Nesticus spp. populations (Hedin 1997a). Although comparisons between genera are not ideal, Nesticus is in a sister family to Latrodectus so some inference may be drawn. Low intraspecific pairwise distances among L. katipo and L. atritus populations, therefore, indicate that populations from which genetic samples were collected may not be genetically isolated or they have not yet undergone complete lineage sorting.

Both maximum likelihood and parsimony analyses revealed that these taxa were paraphyletic. In addition to this, none of the 22 museum specimens of L. katipo and L. atritus examined were found to differ in male and female genitalia. However, marked differences between $L$. katipo and $L$. atritus coloration and distribution (McCutcheon 1976; Forster \& Kingsford 1983; Forster \& Forster 1999) offer support for the current taxonomic designation of these species. Latrodectus are unusual amongst spiders in that their coloration appears to be more useful than genitalia in separating species (Levi 1983). It is possible that although $L$. katipo and $L$. atritus have not been observed mating, this does not preclude the possibility that these species may interbreed. Moreover, if color variation between the species were related to an environmental 


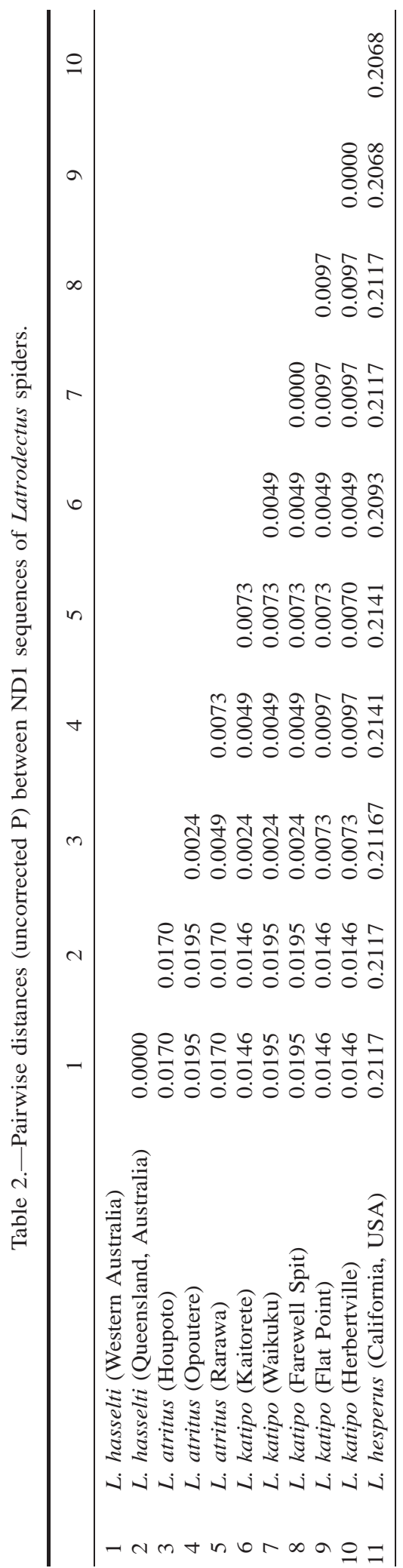

variable, such as temperature, differences in morphology and distribution may be explained. However, we have only data from one mitochondrial gene region and the genetic differences between L. katipo and L. atritus may be due either to gene flow or incomplete lineage sorting. The validity of the species status of $L$. katipo and $L$. atritus could be further explored by the sequencing of more populations with ND1, sequencing with other mitochondrial genes (e.g., COI, which showed over three times more sequence divergence between L. katipo and L. hasselti than ND1: see Garb et al. 2004) or nuclear gene introns, the screening of microsatellites and/or detailed morphological examinations for other possible characters, especially including the mixed populations of the two species mentioned by Forster \& Forster (1999). It would also be worth repeating the rearing experiments reported by Forster \& Kingsford (1983) and Forster \& Forster (1999) with large replicates. Until further work is undertaken L. katipo and L. atritus should be regarded as separate species.

Forster (1995) postulated that the New Zealand widow fauna had been genetically isolated from $L$. hasselti since the fragmentation of Gondwana 60-80 mya (Hayes \& Ringis 1973). If Forster's (1995) hypothesis is true and $L$. hasselti and the New Zealand fauna have been isolated from one another for at least $60 \mathrm{my}$, the maximum pairwise distance (1.95\%) between the L. hasselti and the New Zealand widow fauna suggests a rate of change the ND1 sequence of $0.0325 \%$ per million years, which is 70 times slower than mitochondrial sequence divergence reported in other arthropods (Brower 1994). Forster (1995) had also suggested that all Latrodectus species had a common theridiid ancestor before the break up of Pangea 400 mya (Stevens 1985), which would predate the earliest known Araneoidea fossil (Selden 1989) by 270 my and the earliest spider fossil (Shear et al. 1989) by 20 my. Much of the present day distribution of Latrodectus is likely to be due to dispersal events (Garb et al. 2004) and the low genetic divergence between $L$. hasselti, $L$. katipo and L. atritus in this study and between L. hasselti and L. katipo in Garb et al. (2004) suggests that Latrodectus was not present on New Zealand when it separated from Gondwana 60-80 mya. This assertion is supported 
0.01 substitutions/site

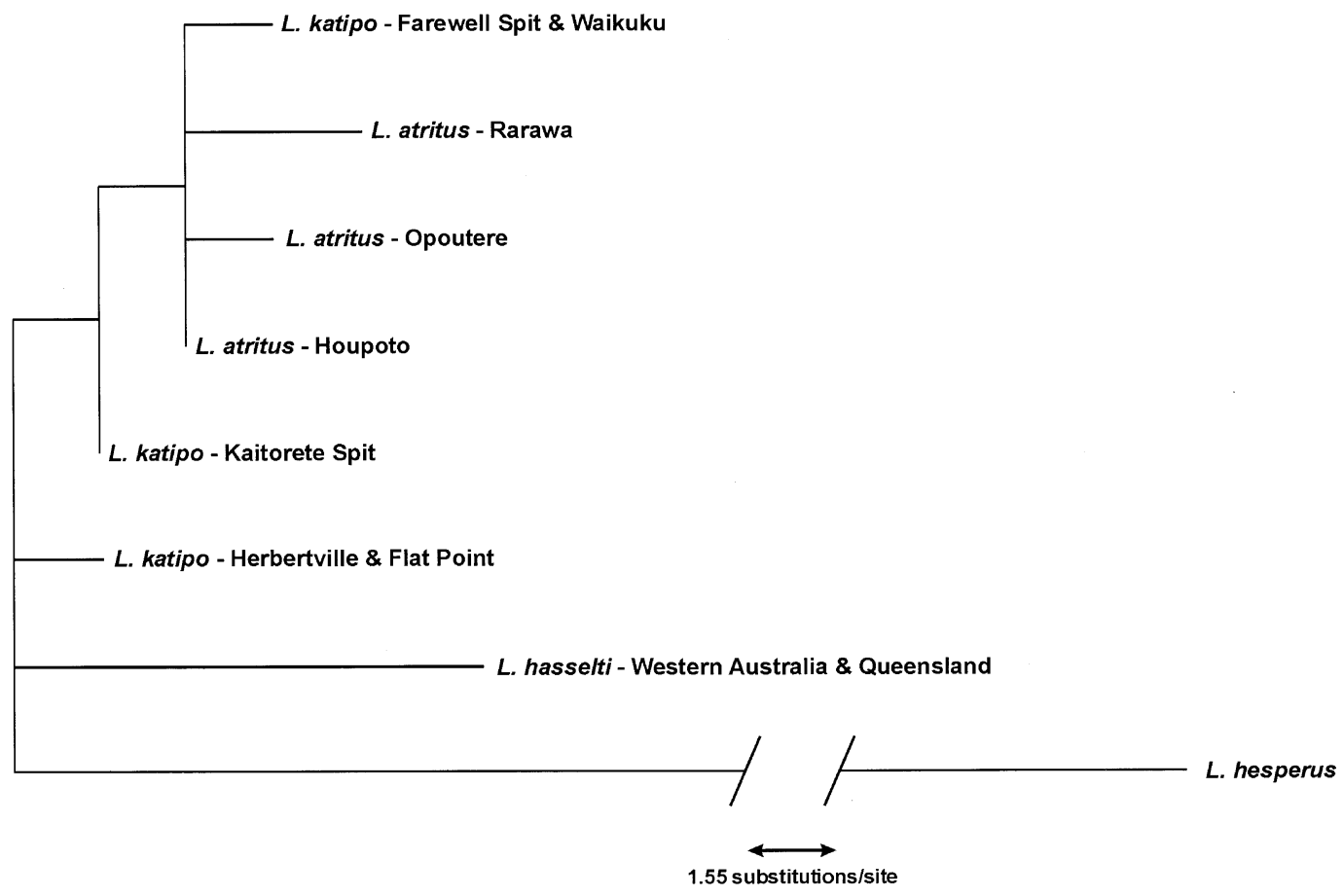

Figure 2.-Maximum likelihood tree, which has identical topology to one of the 12 equally parsimonious trees. Note the long branch of $L$. hesperus. There was not bootstrap support over $60 \%$ in the maximum likelihood analysis and none over $50 \%$ in the parsimony analysis.

by growing evidence that the New Zealand spider fauna has been, and continues to be, influenced by the arrival of spiders from Australia (Vink \& Sirvid 2000; Vink et al. 2002; Vink \& Paterson 2003). Given that suitable $L$. katipo and L. atritus habitat has probably been present in New Zealand for a long time (Stevens et al. 1988) and that the genetic evidence indicates $L$. hasselti is a good disperser, it seems unlikely that L. katipo and L. atritus are recent arrivals to New Zealand. In the absence of datable fossil records, however, it is unlikely that the time L. katipo and L. atritus arrived in New Zealand will be precisely known. Overall, this lack of evidence for isolation between Australia and New Zealand since the Gondwanan break-up agrees with other recent studies of other New Zealand taxa, such as podocarp trees (Pole 1994), galaxiid fish (Waters et al. 2000), hepialid moths (Brown et al. 1999) and various flightless insects (Trewick 2000).

It is possible some gene flow may occur, or has occurred until recently between Australian and New Zealand Latrodectus populations. Greater intraspecific variation found among populations of L. katipo or L. atritus than between the Australian specimens might have resulted from periods of glaciation or rising sea levels that restricted gene flow between $L$. katipo or L. atritus populations in New Zealand, but are unlikely to have affected $L$. hasselti (Stevens 1985; Stevens et al. 1988; Nichols 2001; Trewick 2001). Moreover, Raven (1992) and Main (1992) suggested that L. hasselti may have only recently been introduced to eastern Australia from South Australia, which would explain the lack of genetic variation between the L. hasselti specimens.

Although the ND1 mitochondrial gene region has previously been used to examine intra-specific variation between spider populations (Hedin 1997a; Hedin 1997b; Masta 2000; Johannesen et al. 2002; Maddison \& Hedin 2003; Masta \& Maddison 2002), this gene region did not evolve fast enough to pro- 
vide the definition required to examine gene flow between populations of L. katipo, L. atritus or L. hasselti. Moreover, the low number of samples examined in this project also made it difficult to gain a definitive view of intraspecific gene flow. These problems might be overcome if sequence data from other faster evolving mitochondrial gene regions, such as COI (see Garb et al. 2004), or microsatellites were used and more samples were examined.

\section{ACKNOWLEDGMENTS}

Thanks to Charlie Chambers for collecting assistance. We are grateful to Ding Johnson for collecting L. hasselti from Western Australia, to Robert Raven (Queensland Museum) for providing L. hasselti from Queensland, and to David Voice (Ministry of Agriculture and Forestry) for providing the L. hesperus specimen. We thank Phil Sirvid (Museum of New Zealand), Brian Patrick (Otago Museum) and John Early (Auckland Museum) for the loan of specimens. This research was made possible by funding from the Department of Conservation and the Soil Plant and Ecological Sciences Division, Lincoln University.

\section{LITERATURE CITED}

Benson, D.A., I. Karsch-Mizrachi, D.J. Lipman, J. Ostell, B.A. Rapp \& D.L. Wheeler. 2002. GenBank. Nucleic Acids Research 30:17-20.

Brower, A.V.Z. 1994. Rapid morphological radiation and convergence among races of the butterfly Heliconius erato inferred from patterns of mitochondrial DNA evolution. Proceedings of the National Academy of Sciences of the United States of America 91:6491-6495.

Brown, B., R.M. Emberson \& A.M. Paterson. 1999. Phylogeny of "Oxycanus" lineages of hepialid moths from New Zealand inferred from sequence variation in the mtDNA COI and II gene regions. Molecular Phylogenetics and Evolution 13:463473.

Chamberlin, R.V. \& W. Ivie. 1935. The black widow spider and its varieties in the United States. Bulletin of the University of Utah 25:1-29.

Felsenstein, J. 1985. Confidence limits on phylogenies: An approach using the bootstrap. Evolution 39:783-791.

Foelix, R.F. 1996. The Biology of Spiders. Oxford University Press, New York.

Forster, L.M. 1992. The stereotyped behaviour of sexual cannibalism in Latrodectus hasselti Thorell (Araneae: Theridiidae), the Australian redback spider. Australian Journal of Zoology 40:111.

Forster, L.M. 1995. The behavioural ecology of
Latrodectus hasselti (Thorell), the Australian redback spider (Araneae: Theridiidae): a review. Records of the Western Australian Museum Supplement 52:13-24.

Forster, R.R. \& L.M. Forster. 1999. Spiders of New Zealand and their Worldwide Kin. Otago University Press, Dunedin.

Forster, L.M. \& J. Kavale. 1989. Effects of food deprivation on Latrodectus hasselti Thorell (Araneae: Theridiidae), the Australian redback spider. New Zealand Journal of Zoology 16:401408.

Forster, L.M. \& S. Kingsford. 1983. A preliminary study of development in two Latrodectus species (Araneae: Theridiidae). New Zealand Entomologist 7:431-439.

Garb, J.E., A. González \& R.G. Gillespie. 2004. The black widow spider genus Latrodectus (Araneae: Theridiidae): phylogeny, biogeography, and invasion history. Molecular Biology and Evolution 31:1127-1142.

Gertsch, W.J. 1979. American Spiders. Van Nostrand Reinhold Co, New York.

Griffiths, J.W. 2002. Web site characteristics, dispersal and species status of New Zealand's katipo spiders, Latrodectus katipo and L. atritus. Ph.D. Thesis, Lincoln University, New Zealand.

Griswold, C.E., J.A. Coddington, G. Hormiga \& N. Scharff. 1998. Phylogeny of the orb-web building spiders (Araneae, Orbiculariae: Deinopoidea, Araneoidea). Zoological Journal of the Linnean Society 123:1-99.

Hasegawa, M., K. Kishino \& T. Yano. 1985. Dating the human-ape splitting by a molecular clock of mitochondrial DNA. Journal of Molecular Evolution 22:160-174.

Hayes, D.E. \& J. Ringis. 1973. Sea floor spreading in the Tasman Sea. Nature 243:454-458.

Hedin, M.C. 1997a. Molecular phylogenetics at the population/species interface in cave spiders of the Southern Appalachians (Araneae: Nesticidae: Nesticus). Molecular Biology and Evolution 14: 309-324.

Hedin, M.C. 1997b. Speciation history in a diverse clade of habitat-specialized spiders (Araneae: Nesticidae: Nesticus): inferences from geographic-based sampling. Evolution 51:1929-1945.

Johannesen, J., A. Hennig, B. Dommermuth \& J.M. Schneider. 2002. Mitochondrial DNA distributions indicate colony propagation by single matri-lineages in the social spider Stegodyphus dumicola (Eresidae). Biological Journal of the Linnean Society 76:591-600.

Kumar, S., K. Tamura, I.B. Jakobsen \& M. Nei. 2001. MEGA2: Molecular Evolutionary Genetics Analysis software. Bioinformatics 17:12441245.

Levi, H.W. 1959. The spider genus Latrodectus 
(Araneae, Theridiidae). Transactions of the American Microscopical Society 78:7-43.

Levi, H.W. 1983. On the value of genitalic structures and coloration in separating species of widow spiders (Latrodectus sp.) (Arachnida: Araneae: Theridiidae). Verhandlungen des Naturwissenschaftlichen Vereins in Hamburg 26: 195-200.

Maddison, W.P. \& M.C. Hedin. 2003. Phylogeny of Habronattus jumping spiders (Araneae: Salticidae), with consideration of genital and courtship evolution. Systematic Entomology 28:1-21.

Main, B. 1992. Redbacks may be dinky-di after all: an early record from South Australia. Australasian Arachnology 31:3-4.

Masta, S.E. 2000. Phylogeography of the jumping spider Habronattus pugillis (Araneae: Salticidae): recent vicariance of sky island populations? Evolution 54:1699-1711.

Masta, S.E. \& W.P. Maddison. 2002. Sexual selection driving diversification in jumping spiders. Proceedings of the National Academy of Sciences of the United States of America 99:44424447.

McCrone, J.D. \& H.W. Levi. 1964. North American widow spiders of the Latrodectus curacviensis group (Araneae: Theridiidae). Psyche 71:12-27.

McCutcheon, E.R. 1976. Distribution of the katipo spiders (Araneae: Theridiidae) of New Zealand. New Zealand Entomologist 6:204.

Nichols, R. 2001. Gene trees and species trees are not the same. Trends in Ecology and Evolution 16:358-364.

Parrott, A.W. 1948. The Katipo spider of New Zealand (Latrodectus hasseltii Thorell). Records of the Canterbury Museum 5:161-165.

Pole, M. 1994. The New Zealand flora-entirely long-distance dispersal? Journal of Biogeography 21:625-635.

Posada, D. \& K.A. Crandall. 1998. MODELTEST: testing the model of DNA substitution. Bioinformatics 14:817-818.

Raven, R.J. 1992. Redback spiders, black widows and their kin. Presidential address. News Bulletin of the Entomological Society of Queensland 20: 4-8.

Selden, P.A. 1989. Orb-web weaving spiders in the early Cretaceous. Nature 340:711-713.

Shear, W.A., J.M. Palmer, J.A. Coddington \& P.M. Bonamo. 1989. A Devonian spinneret: early evidence of spiders and silk use. Science 246:479481.

Stevens, G.R. 1985. Lands in Collision. DSIR Publishing Centre, Wellington.
Stevens, G.R., M. McGlone \& B. McCulloch. 1988. Prehistoric New Zealand. Heinemann Reed, Auckland.

Swofford, D.L. 2002. PAUP*: Phylogenetic Analysis Using Parsimony (*and Other Methods), Version 4.0b10. Sinauer Associates, Sunderland, Massachusetts.

Thompson, J.D., T.J. Gibson, F. Plewniak, F. Jeanmougin \& D.G. Higgins. 1997. The CLUSTAL $\mathrm{X}$ windows interface: flexible strategies for multiple sequence alignment aided by quality analysis tools. Nucleic Acids Research 25:48764882.

Trewick, S.A. 2000. Molecular evidence for dispersal rather than vicariance as the origin of the flightless insect species on the Chatham Islands, New Zealand. Journal of Biogeography 27: 1189-1200.

Trewick, S.A. 2001. Scree weta phylogeography: surviving glaciation and implications for Pleistocene biogeography in New Zealand. Journal of Zoology 28:291-298.

Urquhart, A.T. 1890. Descriptions of new species of Araneidae. Transactions and Proceedings of the New Zealand Institute 22:239-266.

Vink, C.J., A.D. Mitchell \& A.M. Paterson. 2002. A preliminary molecular analysis of phylogenetic relationships of Australasian wolf spider genera (Araneae, Lycosidae). Journal of Arachnology 30:227-237.

Vink, C.J. \& A.M. Paterson. 2003. Combined molecular and morphological phylogenetic analyses of the New Zealand wolf spider genus Anoteropsis (Araneae: Lycosidae). Molecular Phylogenetics and Evolution 28:576-587.

Vink, C.J. \& P.J. Sirvid. 2000. New synonymy between Oxyopes gracilipes (White) and Oxyopes mundulus L. Koch (Oxyopidae: Araneae). Memoirs of the Queensland Museum 45:637-640.

Waters, J.M., J.A. Lopez \& G.P. Wallis. 2000. Molecular phylogenetics and biogeography of galaxiid fishes (Osteichthyes: Galaxiidae): dispersal, vicariance, and the position of Lepidogalaxias salamandroides. Systematic Biology 49:777795.

White, T.J., T. Bruns, S. Lee \& J. Taylor. 1990. Amplification and direct sequencing of fungal ribosomal RNA genes for phylogenetics. Pp. 315322. In PCR Protocols: A Guide to Methods and Applications. (M.A. Innis, D.H. Gelfand, J.J. Sninsky \& T.J. White, eds.). Academic Press, San Diego.

Manuscript received 5 May 2004, revised 1 August 2004. 